\title{
O homem dos mil truques: Chomón animador ${ }^{1}$
}

\author{
Paulo Roberto de Carvalho Barbosa \\ UFMG \\ prcbarbosa@ig.com.br
}

\section{Introdução}

No início do século $\mathrm{XX}$, um espanhol trotamundos circulou por algumas das principais companhias de cinema europeias, trabalhando como especialista em trucagens. Prolífico, deixou seu artesanato visual em cerca de 500 filmes, seus e de outros diretores, entre curtas, médias e longas-metragens. Segundo Víctor Aurelio Chomón y Ruiz nasceu em 1871, na cidade de Teruel, autonomia de Aragão. Mudou-se para a França em 1895, ano de estreia do cinematógrafo Lumière. Estima-se que tenha travado contato com projeções de imagens móveis em seus primeiros anos em Paris. A tecnologia do cinema, contudo, foi-Ihe apresentada somente pela virada do século, na oficina de pintura de películas do mágico Georges Méliès, com quem trabalhou durante dois anos. Os primeiros filmes vieram em 1902, quando se transferiu para Barcelona, disposto a montar, na capital catalã, a própria oficina de pintura de películas e a primeira produtora espanhola de que se tem notícia. Começava aí uma carreira de quase três décadas dedicadas ao cinema, interrompida pela sua morte, em 1929, após as filmagens de um documentário no Marrocos.

Fotógrafo, documentarista, inventor de aparatos, Chomón foi um cineasta plural. Transitou pelas muitas transformações do cinema nas décadas inaugurais do novo século, sempre em sintonia com as mudanças em curso. ${ }^{2}$ A sua grande vocação aflorou no filme de truques, aperfeiçoado ao longo de numerosos títulos, marcados pela engenhosidade técnica e por uma fantasia desbordante. Filmes de truques já se faziam presentes em sua fase barcelonesa, etapa em que iniciou uma intensa colaboração com a Pathé-Frères. Pintava películas para a prestigiosa companhia francesa, além de fotografar os títulos dessas películas, vertidos para

\footnotetext{
1 Uma primeira versão deste artigo foi publicada nos anais da Conferência Internacional de Cinema de Avanca (Portugal), realizada em 2013.

2 Mais sobre o trânsito de Chomón pelas transformações do cinema em suas primeiras décadas, conferir: Do truque ao efeito especial: o cinema de Segundo de Chomón (Barbosa, 2014).
} 
o idioma espanhol. As muitas habilidades do realizador interessavam à Pathé, que o convidou a integrar o seu staff de diretores em 1904. De 1905 a 1910, Chomón realizou 132 filmes para a companhia, 100 dos quais, títulos próprios. Trabalhava em ritmo frenético, rodando filmes de truques, fantasmagorias, filmes de perseguição, féeries, atualidades, cenas cômicas. O ingresso na firma vinha num momento em que a Pathé expandia suas atividades, abrindo escritórios para comercializar seus produtos em cidades como Londres, Moscou, Berlim, Viena, Milão, Nova York e Xangai. Aqueles eram tempos de concorrência com a Star Film de Méliès, e a Chomón cabia realizar, na Pathé-Frères, películas capazes de competir, em matéria de trucagens e pirotecnias, com as de seu expatrão, maior nome do filme de truques até ali.

Em contato com novas influências, o trabalho de Chomón oxigenou-se. Seus filmes receberam cores por estênceis mecânicos, ${ }^{3}$ foram estrelados por atores profissionais e se beneficiaram das novidades técnicas em voga entre os diretores da casa. Particularmente a animação destacou-se entre as técnicas utilizadas pelo cineasta, ocupando um lugar privilegiado em sua filmografia a partir daí. De 1907, ano de estreia da técnica, até meados dos anos 1920, quando Chomón realizou seus últimos filmes, perto de quarenta títulos no catálogo do espanhol trouxeram cenas animadas. O presente artigo aborda as principais animações deste "imperador dos truques", ${ }^{4}$ detendo-se nas suas contribuições para a animação, uma área de criação então em busca de fundarse como linguagem, ainda hoje em fase de invenção. Sem perder de vista o processo criativo do diretor, o artigo percorre as prospecções de Chomón em torno da fotografia quadro a quadro, desdobrada em variações como a animação de bonecos, de silhuetas e o pixilation. Como conclusão, destaca o modo pelo qual o espanhol procurou fazer, da animação, um fim em si mesmo, para além de um simples efeito visual.

\section{I - A imagem se anima}

Centenária como o próprio cinema, a técnica da animação remonta aos primeiros anos das imagens em movimento. Em 1898, Stuart Blackton e Albert E. Smith, fundadores da companhia Vitagraph, rodavam um filme no topo de um edifício

\footnotetext{
3 Mais sobre as primeiras técnicas de colorização de filmes em o primeiro cinema em cores: tecnologia e estética do filme colorido até 1935 (Barbosa, 2014).

4 A distinção de "imperador dos truques" foi conferida a Chomón pelo italiano Giovanni Pastrone, produtor conhecido pela usura em distribuir elogios aos seus subordinados.
} 
em Nova York. A dupla fazia as tomadas de uma cena concebida para receber o truque da pausa para substituição. ${ }^{5}$ Por um lapso, a nuvem de vapor de um gerador do prédio, que pairava ao fundo durante as filmagens, foi fotografada sucessivas vezes, em diferentes posições. Projetado o filme, Blackton e Smith viram a nuvem aparecer e desaparecer rapidamente na tela, gerando uma inesperada ilusão de movimento. O efeito não foi retomado senão em 1906, quando ocorreu a Blackton que, se nuvens podiam ter seu movimento manipulado daquela maneira, desenhos também se prestariam a tanto. A ideia resultou em Humorous phases of funny faces, primeiro filme a apresentar cartoons animados em suas imagens e ponto de partida para outras animações de Blackton. ${ }^{6}$

Humorous phases of funny faces traz uma série de desenhos a giz ganhando forma num quadro negro, primeiro, pela mão de um desenhista, depois, sem qualquer ajuda externa. Causou frisson o truque empregado na película, capaz de fazer com que cartoons se autocompletassem num quadro, dispensando o auxílio de desenhistas. Se os desenhos animados de Blackton deixaram plateias boquiabertas, o lançamento seguinte do norte-americano despertou perplexidade ainda maior. The haunted hotel (EUA, Blackton, 1907) conta a história de viajante que se hospeda num hotel rural, em cujas dependências ocorre uma série de eventos bizarros. A certa altura da película, pratos, copos, talheres e guardanapos movimentam-se sobre uma mesa para servir, sem a intervenção de mãos humanas, um insólito desjejum ao hóspede.

Os espectadores não foram os únicos a se impressionar com The haunted hotel. Também os profissionais de cinema tomaram-se de admiração pela fita, intrigados com a trucagem utilizada na cena do desjejum. O rumor foi tal que Thomas Edison, produtor de The haunted hotel, dispôs-se a revelar o truque aplicado nas imagens, durante uma passagem por Londres. Entrevistado para uma publicação local, explicou ter sido o café "assombrado" do filme fruto de um uso diferenciado da câmera, preparada para a captura de um fotograma por vez, no lugar de 16 , como nas tomadas tradicionais. Por esse procedimento, mais

\footnotetext{
$5 \mathrm{O}$ truque da pausa para substituição implicava interromper o funcionamento da câmera durante as filmagens, substituir pessoas ou objetos no seu campo visual e retomar o funcionamento da máquina, produzindo a impressão de que elementos da cena haviam desaparecido ou sido substituídos por outros.

${ }^{6}$ Mais sobre os primórdios da animação fotográfica em Before Mickey: The Animated Film 1898 1928, de Donald Crafton.
} 
tarde chamado animação em stop-motion, era possível emprestar ilusão de movimento aos mais diferentes objetos sólidos, os quais se comportavam, na tela, como se tomados por sortilégios mágicos.

Ao tempo da passagem de Edison por Londres, Chomón andava pela capital britânica, cumprindo agenda de filmagens. Assistiu mesmerizado a The haunted hotel e passou dias tentando desvendar a trucagem usada na película. Só teve a curiosidade satisfeita ao ler a entrevista de Edison, contando o segredo do stopmotion. De volta a Paris, estreou a técnica em La maison ensorcelée, filme que se inicia com três amigos abrigando-se numa casa mal-assombrada para fugir de uma tempestade inclemente. Fatos surpreendentes acontecem no interior da casa, onde, a exemplo de The haunted hotel, utensílios domésticos deslocam-se sobre uma mesa para servir um improvável café aos hóspedes intrusos.

Em Le sculpteur moderne (1908), seu filme seguinte, o stop-motion aparece para animar um material em fase de lançamento, a plastilina (ou massa de modelar). Julienne Mathieu, esposa do diretor, é quem apresenta ao espectador esse e outros truques do marido, fazendo correr as cortinas de um palco. Ao fundo, vê-se um retângulo negro e emoldurado, onde surgem figuras diminutas, à semelhança de estátuas. São homens vestidos de guerreiros romanos e mulheres marmóreas, postos no retângulo por meio de sobreimpressões.

Após o desfile das estátuas-vivas em miniatura, Julienne monitora a transformação de blocos de plastilina em esculturas assinadas pelo artista popular Georges Lucien Guyot, colaborador circunstancial de Chomón. Julienne mostra a massa plástica tomando a forma de uma cartola, em cujo interior abrigam-se dois filhotes de gato. No quadro seguinte, observa a transmutação da plastilina numa bota surrada, tendo ratinhos como inquilinos. Um macaco tabagista, uma águia, um jacaré e a cabeça de um leão (fig. 1) também são mostrados ao espectador pela moça, que encerra o filme recompondo, em câmera reversa, o corpo de uma velha recurva. 

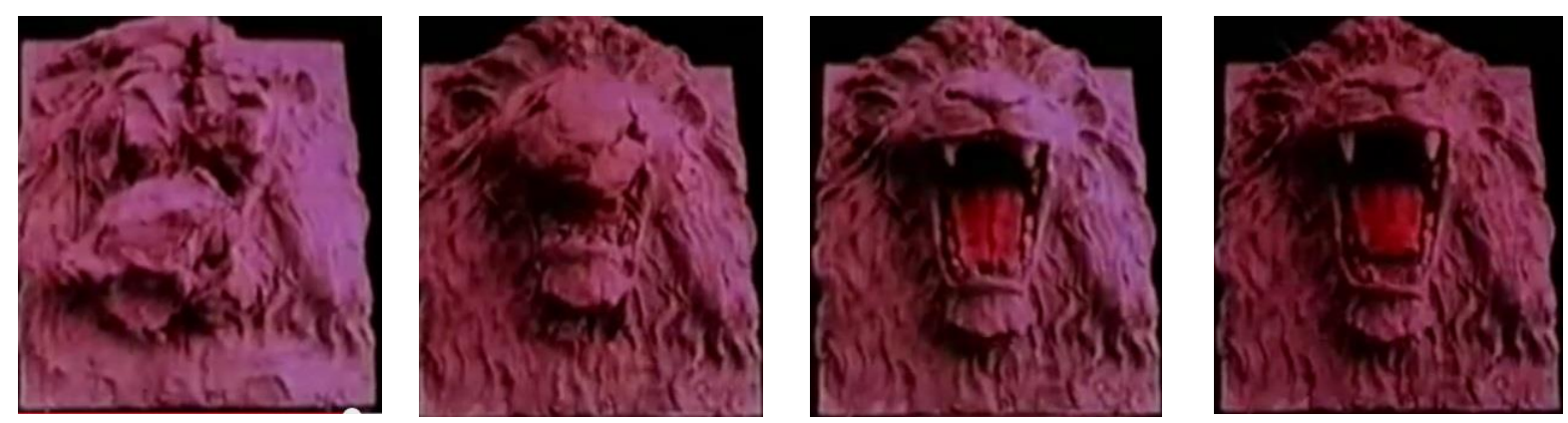

Figura 1 - Sculpteur moderne

Em 1908, a animação ensaiava seus primeiros passos. Com esta série de iluminuras móveis, Chomón flertava com a técnica, sondando seus limites. No título, a fita diz a que vem: "escultor moderno", aqui, é o próprio cinema, ocupado em engendrar corpos e objetos cinéticos a partir de blocos de massa plástica. Gatos, leões, macacos, ratos, botas e até cadarços cobram vida na tela, movendo-se sobre um pedestal. O stop-motion viabiliza esses fenômenos, soprando vida à massa amorfa por meio de seus dotes fotográficos. Operação supervisionada por Chomón, gestor do carrossel de imagens vistas no filme, ele também um moderníssimo escultor.

Domínio de poucos em 1908, a animação recebia gratificada as investidas de Chomón. O experimentalismo pautava o caminho do diretor pela nova técnica, como se verifica em Le sculpteur moderne, mas também em Les ombres chinoises, apontado pelo pesquisador Juan Gabriel Tharrats como introdutor da animação de silhuetas no cinema (1990: 30). Uma dupla de dançarinas chinesas abre o filme, girando guarda-sóis coloridos. As chinesas encaixam uma tela retangular sobre um suporte ao fundo e, após um corte, essa tela ocupa toda a extensão do ecrã, mostrando uma animação de silhuetas recortadas em papel. Uma bailarina que pula corda, objetos domésticos que se combinam e recombinam em curiosos antropomorfismos, eis algumas das imagens deste filme caprichoso, menos interessado em narrar do que em exibir-se.

Se Les ombres chinoises distingue-se pela prodigalidade técnica, convém informar como foi realizado. Para animar a série de recortes em cartolina branca do filme, Chomón usou uma mesa de vidro opaco, iluminada por baixo, e uma câmera em eixo vertical, maquinaria comum aos animadores ainda nos dias de hoje. Quadro por quadro, o diretor fotografou os recortes em diferentes posições, 
operação da qual resultam imagens brancas movendo-se sobre um fundo preto. Chomón preferiu utilizar, contudo, o negativo do filme para a versão final de Les ombres chinoises, de modo que o que se vê, na tela, é o preto-e-branco invertido.

\section{II - A vida dos objetos}

A jornada exploratória do diretor pela animação o levará ainda a outras descobertas. Em El hotel eléctrico, Chomón envereda pela modalidade da fotografia quadro a quadro que se dedica a emprestar movimento artificial a corpos humanos. Hoje conhecida como pixilation, a técnica permite à figura humana traçar, na tela, movimentos impensáveis pela tomada de cena tradicional. Dava aos corpos humanos, na primeira década do século $\mathrm{XX}$, uma mobilidade robótica, maquínica, ideal para reverberar as mudanças pelas quais o homem e o cenário urbano passavam, em face da chegada das novas tecnologias. Híbrido, El hotel eléctrico combina cenas em live-action a cenas em pixilation e em stop-motion para esquadrinhar a rotina de um hotel cujos serviços são prestados de maneira inteiramente automática, por obra e graça da energia elétrica.

El hotel eléctrico abre com lobby de hotel, onde casal de turistas é recebido por um solícito porteiro. O porteiro dispensa camareiros para o transporte da bagagem de Laure e Bertrand: manejando um sistema de pequenas alavancas, faz as malas partirem, sozinhas, rumo à suíte onde se hospedará o casal. $\mathrm{Na}$ suíte, as malas se abrem, deixando que escovas, meias, calças e camisas saiam dali e se auto-organizem nas gavetas de uma cômoda. Obedientes a relações de causa e efeito, os planos iniciais do filme cumprem a missão de descrever o percurso das malas e dos objetos, introduzindo o espectador no maravilhoso mundo das comodidades elétricas.

O casal apresenta-se no cenário da suíte, onde outras surpresas o esperam. Empoeirados pela viagem, Laure e Bertrand procuram se arrumar. Bertrand também maneja alavancas, e um close-up nas suas botas mostra uma bateria de escovas e flanelas engraxando o calçado, em mais uma sessão de stop-motion. Novos toques nas alavancas conduzem Laure e sua cadeira para o fundo do quarto, após o que, um close-up enquadra o rosto da moça, penteada por escovas animadas (figura 2). Sem letreiros ou descontinuidades, o filme narra-se a si mesmo, com os truques incorporando-se à história de modo quase natural. 


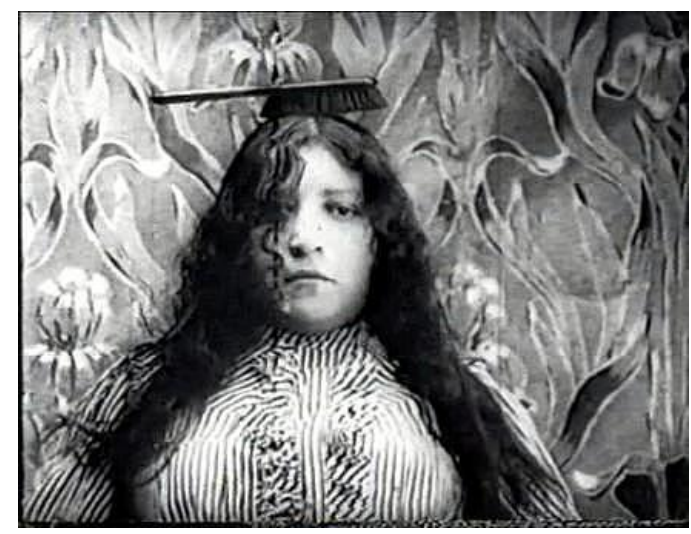

Figura 2 - Escova animada penteia Laure

Prossegue o desfile de comodidades elétricas, sempre auxiliado pela animação. Agora é Bertrand quem cuida do visual: um close-up de seu rosto mostra navalha, pente e pincel no aplicado trabalho de barbeá-lo. Novo movimento nas alavancas faz vir, do fundo do quadro, uma escrivaninha, de onde saem papel e caneta, que escreve um cartão-postal, via stop-motion, aos familiares de Laure. Terminado o "postal elétrico", os hóspedes merecem um descanso. Entrementes, um funcionário bêbado aperta as chaves do painel de controle do hotel, causando-Ihe uma pane. É o suficiente para que a suíte se precipite num redemoinho de camas, cadeiras, mesas e armários, com Laure e Bertrand terminando o filme presos a uma barafunda de objetos.

Eis a modernidade, tal como vista por Chomón: a princípio, acena com benesses, sintetizadas na parafernália elétrica de um hotel automatizado até o limite. Não demora em trazer transtorno, porém, como ilustra o curto-circuito no sistema elétrico da casa, precipitando o hotel num completo descontrole. Pensada para ser uma ferramenta em prol do humano, a panóplia moderna só é útil, aqui, para mergulhar o casal de hóspedes no caos. Fonte de problemas, inaugura um tempo mais de incertezas do que de facilidades, inspirando a desconfiança do realizador, que se indispõe com o furor hipertecnológico da nova época.

A crença na tecnologia do cinema, contudo, subsiste, conquanto vista sob o olhar oblíquo de Chomón. Investigar as potencialidades do cinematógrafo mantém-se entre as preocupações do diretor, que, por meio de truques fotográficos, leva seus personagens a transitarem por situações as mais absurdas. O desvio pelo incomum, sabe-se, é uma das prerrogativas do humor, inclusive em sua versão 
cinemática, usuária contumaz de todo tipo de trucagens. Assim também o gênero fantasmagórico, nada reverente ao "curso natural das coisas" e, por isso, recebedor de farta dose de truques. Dentre as muitas artimanhas encontradas no baú do espanhol, o stop-motion prestava-se como nenhuma outra a materializar os delírios insanos das fantasmagorias. Em Le rêve des marmitons (1908), é o recurso de que se vale para pôr em cena mãos que se separam de seus corpos e continuam vivas, num protossurrealismo que faria a delícia de Salvador Dalí.

Le rêve des marmitons abre com as trapalhadas de um grupo de ajudantes de cozinha nos intramuros de um castelo. Ali, ninguém trabalha, e a fuzarca dos cozinheiros é tal que um bilioso duende aparece para preparar uma beberagem a fim de que todos adormeçam. O duende se aproveita para, a golpes de facão, cortar as mãos dos cozinheiros enquanto dormem. Tornadas móveis pelo stopmotion, as mãos desatam a picar cenouras, batatas e outros legumes, feitiço somente terminado quando o cozinheiro-chefe desperta para ver o trabalho de cozinha finalmente concluído. É a animação a serviço do ócio, materializando o sonho de que, um dia, as mais aborrecidas tarefas domésticas se realizem por si próprias, como neste conto de fadas protossurreal.

\section{III - Mundo bizarro}

O stop-motion, este brinquedo novo nas mãos de Chomón: com a técnica, até as moscas podiam aspirar a um papel numa película. E uma pequena mosca é, de fato, o que o diretor põe em cena, a um dado momento de Le rêve des marmitons. Para desenhar uma caricatura na calva de um dos cozinheiros, bem entendido: durante o sono do empregado, o inseto molha as patas num frasco de tinta nanquim e faz uma série de estripulias gráficas sobre a sua luzidia cabeça. ${ }^{7}$ Se, por obra do stop-motion, uma mosca pode ser coadjuvante de um filme do espanhol, sombrinhas a desfilar pelas ruas e dançando ao som de uma banda de circo também merecem lugar entre as fulgurações em celuloide de Chomón. Essa ideia apresenta-se em Symphonie bizarre, filme que, a exemplo de Le rêve des marmitons, faria jus ao rótulo de surreal, caso, em 1908, o termo já houvesse sido inventado.

\footnotetext{
7 O stop-motion possui um mito fundador, com Chomón no papel de protagonista, difundido por Carlos Fernández Cuenca (1972: 49-50). Para Cuenca, o espanhol teria "descoberto" o stop-motion em Barcelona, no tempo em que fotografava títulos de filmes para a Pathé. Ocupava-se Chomón de seu trabalho, quando uma mosca pousou numa de suas cartelas de títulos, sendo fotografada sucessivas vezes. O inseto ficou evidente depois de revelada a película, que mostrou a mosca descrevendo movimentos "demenciais" sobre a tela. Trata-se, porém, de uma lenda, e a primazia da técnica é para o norte-americano Stuart Blackton.
} 
Symphonie bizarre já começa de modo inusual: num muro de rua, desenha-se a sombra que uma banda de músicos teria, se acaso estivesse ali. Surpresa: os músicos, em número de oito, aparecem para ocupar seus postos junto às sombras, tocando bumbo, trompete, acordeom, clarinete, corneta e violino. Externas mostram a banda numa procissão pelas ruas, ao término da qual o homem do bumbo recolhe, um a um, os companheiros de orquestra para dentro de seu instrumento. O braço do tocador de bumbo, porém, fica do lado de fora para continuar a bater o tambor, que rola pela calçada num zigue-zague aleatório (figura 3).

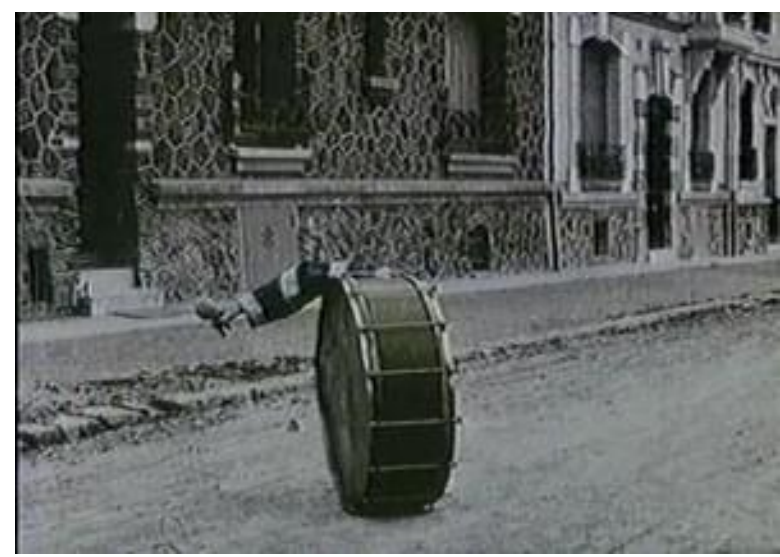

Figura 3 - Symphonie bizarre

Em 1909, Chomón voltou muitas vezes à seara do fantástico. A casa assombrada é de novo tema de uma fantasmagoria em Une excursion incohérente, filme que traz imagens de um pesadelo sinistro, materializado por uma animação de silhuetas. Acompanhado de dois criados, casal embarca num coche rumo ao campo. O grupo desembarca para um piquenique na relva, mas é interrompido por incidentes estranhos e uma chuva torrencial. De volta ao coche, casal e criados seguem viagem até a casa em que irão se hospedar. Lá chegando, os empregados desembarcam e dirigem-se para a cozinha, enquanto o casal sobe ao andar de cima para dormir. Os criados tentam preparar algo para comer, mas são surpreendidos por uma panela que ganha feições grotescas no fogão, levando a dupla a desistir da malfadada empreitada culinária.

No segundo andar, o casal ensaia dormir. O ritual de recolhimento da esposa é espiado pelo marido, como se assistisse a uma projeção de cinema, no lençol estendido entre a sua cama e a cama da mulher. Nesse ecrã improvisado, 
descortina-se um pesadelo, obtido pela animação de silhuetas. Entre o pé e a cabeça da mulher, constrói-se uma ponte, por onde trafega um trem. O trem segue até a boca da velha, que o engole. Uma casa também se forma na cabeça da mulher, cuja porta se abre para que um camponês saia dali com um carrinho de mão rumo ao trabalho, entre outros desatinos. O pesadelo só termina quando dois homens chifrudos saltam da boca da velha, para deixar o marido em pânico (figura 4). Espavorido, o homem corre e se atira numa cisterna, seguido pela mulher e pelos criados, que o retiram dali com um balde. Fecha-se a história com os criados bombeando água da barriga do pobre.

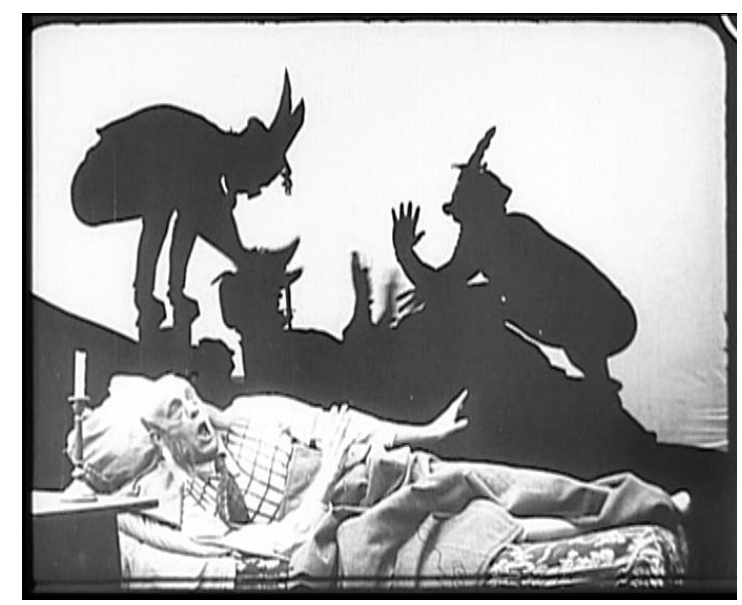

Figura 4 - Une excursion incohérente

Em Une excursion incohérente, transparece, mais uma vez, a excelência técnica de Chomón. Para animar o filme, o espanhol utilizou um equipamento de sua própria manufatura, apto à fotografia quadro a quadro, batizado de aparato $12 .^{8}$ Nas primeiras câmeras, para a captura dos dezesseis fotogramas necessários um segundo de filme, devia-se girar duas vezes a manivela da máquina. Com uma só volta na manivela, capturavam-se oito fotogramas, e com 1/8 de volta, apenas um fotograma. Para que a passagem da película não fosse feita da maneira tradicional, Chomón modificou sua câmera de modo que o filme avançasse $1 / 8$ a cada giro de manivela. Isso permitia a captura de um único fotograma por vez, viabilizando difíceis animações, como a presente em Une excursion incohérente.

8 O aparato 12 de Chomón era também dotado de um mecanismo contador de fotogramas, permitindo-lhe maior precisão no truque de sobreimpressão, bem como no da pausa para substituição. 
Técnica é arte, mas arte não é técnica, ensina o provérbio oriental. Chomón era não só um conhecedor das entranhas cinematógrafo, mas um operoso inventor de imagens. As silhuetas animadas são o que marido vê de sua cama, como se assistisse a uma sessão de cinema. Estapafúrdias, apresentam o dispositivo cinematográfico como uma máquina de exibir pesadelos. O adjetivo "incoerente" não figura por acaso no título do filme, portanto. Aplicável aos eventos estrambóticos projetados no lençol, aponta para disparates e contradições inerentes aos novos tempos. E o faz numa altura em que os muitos absurdos hoje vistos como normais não haviam se cristalizado em regra, sendo entendidos, antes, como frutos vistosos de uma era coroada pela racionalidade instrumental.

Antes dos surrealistas, o Movimento dos Incoerentes ${ }^{9}$ já cuidava de descarregar as baterias contra o emergente racionalismo moderno. Os incoerentes, como se autodenominou um coletivo de artistas e escritores inconformistas de fins do século XIX, preconizavam uma arte anárquica, irreverente, zombeteira do primado da razão técnica sobre a sensibilidade. Em lugar das leis da lógica, propunham a patafísica, "lei que governa as exceções e explica o universo adicional a este". Chomón simpatizava com o movimento e dava-Ihe a sua contribuição em filme: Une excursion incohérente mescla cenas em live-action a imagens animadas para, num mix de diferentes substâncias visuais, destilar ceticismo contra a tonitruante era moderna, depositária das esperanças de redenção humana através da máquina e da razão instrumental.

\section{IV - No encalço do pickpocket}

Corria o ano de 1909, e o contrato de Chomón com a Pathé, previsto para expirar em 1910, ia chegando ao fim. Malgrado a companhia não fizesse menção de renovar a tratativa, o realizador dedicava ao trabalho o entusiasmo de sempre. Filmes infantis, cenas cômicas, fantasmagorias, filmes de perseguição, foram muitos os gêneros que estamparam animações chomonianas no fim de ciclo francês do diretor. Slippery Jim (1909) é um filme de perseguição dessa fase, trazendo duas atrevidas animações. Usuária de outros truques, a película

\footnotetext{
9 Hoje praticamente esquecido pelos historiadores, o Movimento dos Incoerentes foi fundado em 1880, em Paris, pelo escritor Jules Lévy. Propunha uma arte insuflada pelo absurdo, pelos pesadelos e pela visão de mundo das crianças.
} 
injeta fantasia num gênero até então refratário às trucagens e estruturado numa repetição incessante de cenas filmadas a plein air.

Numa delegacia, dois policiais exibem um ladrão de carteiras ao comissário. Os guardas recebem ordens para atar as pernas do pickpocket a correntes, levandoo para fora de quadro. O ladrão senta-se calmamente na cela, enquanto os policiais prendem argolas de ferro às suas canelas. À saída de cena dos homens da lei, os pés do pickpocket são vistos, num close-up e por obra do stop-motion, desenroscando-se de suas canelas para livrar-se das correntes (figura 5). Seguese uma vertiginosa perseguição ao ladrão, e é novamente a animação, desta vez de recortes fotográficos, que mostra o pickpocket numa bicicleta capaz de sobrevoar o mar, dar piruetas no céu, pousar no teto de um trem em movimento e voltar à rua, para deleite das audiências, extasiadas com a ubiquidade do ladrão.

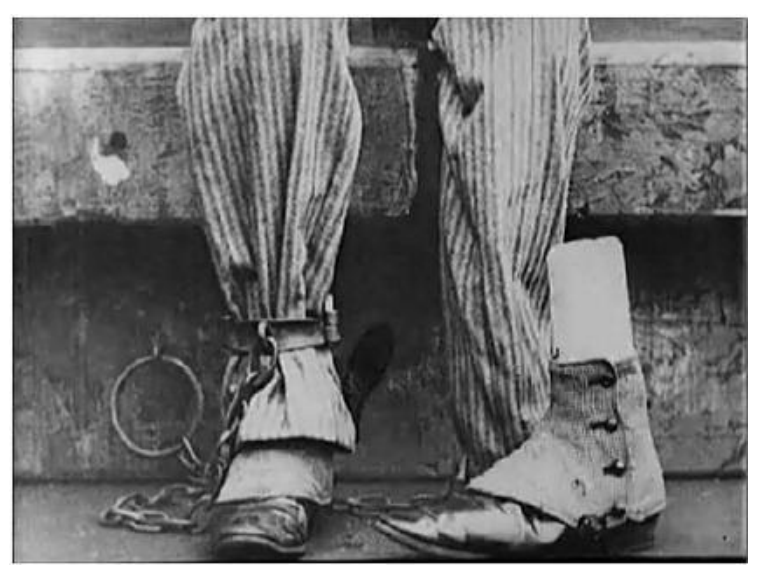

Figura 5 -Slippery Jim

A combinação entre fantasia e engenhosidade técnica vista em Slippery Jim é retomada por Chomón em El teatro eléctrico de Bob (1909), raro exemplo de fita com cenas em stop-motion em praticamente toda a sua extensão. Um único plano em live-action é usado para abrir o filme, o qual apresenta um grupo de crianças entediadas na sala de uma casa. Para espairecer, as crianças montam um teatro de brinquedo, cujo palco dá a ver as evoluções de dois bonecos articulados. Animados pelo stop-motion, os bonecos lutam boxe, rolam pelo chão e simulam um duelo de espadachins. Um palhaço exercitando-se em barras horizontais serve para finalizar esta película menos interessada em narrar do que em demonstrar a capacidade do cinematógrafo para dar vida a bonecos infantis, objetivo alcançado com louvor. 
Cabe menção ainda a um último título dessa fase final de Chomón na Pathé, no qual se verifica o pixilation aplicado de modo particularmente inventivo. Em L'hotel hanté (1909), o diretor põe à vista homem que procura repousar no quarto de um hotel, onde dois fantasmas giram sua cama ao acaso. Os fantasmas desaparecem, e uma cadeira entra em cena para enlouquecer o hóspede. O móvel gira em torno de si mesmo, replica-se em dezenas de outras cadeiras, revolve-se, sacode-se, esperneia. Submetido a esses dramáticos volteios, o homem parece rendido aos imperativos de uma cadeira determinada a atazaná-lo. Metafórico do vórtex de mudanças pelas quais passava o cotidiano urbano àquela altura, o filme é mais um arguto comentário do diretor sobre o agitado panorama moderno, cada vez mais perpassado de novos estímulos, produzidos pela escalada tecnológica e pelo infernal modus vivendi contemporâneo. Um panorama que não tardaria em se complexificar também ao nível da política, a ponto de encontrar sua primeira grande crise no ruinoso conflito conhecido como Primeira Guerra Mundial.

\section{V - Bonecos em guerra}

Vencido o contrato de Chomón com a Pathé Frères, o diretor não abandonou o cinema. Voltou a Barcelona em 1910 para fundar uma nova produtora, em sociedade com um empresário catalão. ${ }^{10} \mathrm{Em}$ dois anos na Espanha, realizou cerca de três dezenas de filmes, dos quais sobrevivem apenas cinco (três ficções e dois documentários). Nada exclui que Chomón tenha utilizado a fotografia quadro a quadro nesta segunda fase espanhola. Não há, porém, evidência acerca disso, já que nenhuma das películas remanescentes apresenta cenas animadas. A animação reaparece de modo mais claro no período que se segue ao fracasso dos empreendimentos do diretor em solo ibérico. Mais precisamente, quando, a partir de 1912, o espanhol passa a integrar a Itala Film, uma das mais importantes companhias italianas em atividade naquele início de década.

Na Itália, o espanhol colaborou para a realização de centenas de longasmetragens, da Itala Film e de outras produtoras. Trabalhava em diversas frentes, como fotógrafo, diretor, iluminador e operador de truques. As películas próprias sofreram um decréscimo, tendo em vista o ambiente industrial, avesso aos voos

\footnotetext{
10 Em Barcelona, Chomón fundou a produtora Chomón y Fuster, que, não obstante uma intensa atividade, entrou em falência ao cabo de nove meses. Endividado e sem um estúdio onde filmar, o diretor foi reabsorvido pela Pathé, que decidiu abrir uma filial da empresa na Espanha, tendo Chomón como seu realizador. Na Iberico Film, o espanhol rodou documentários sobre especificidades regionais espanholas, deixando de lado o vórtex criativo da Chomón y Fuster.
} 
artísticos individuais. Eram novos tempos, e cumpria adotar uma postura anônima no país da bota, condizente com o pragmatismo em voga na indústria, dentro e fora da Itália. Filmes próprios, Chomón realizou somente enquanto não esteve envolvido nos projetos regulares da companhia, algo bastante raro. Ainda que poucos, os títulos assinados pelo espanhol na Itália preservaram algo da velha obsessão pela animação, como se verifica em La guerra i il sogno de Momi (1917), uma codireção entre Chomón e Pastrone. O filme divide-se em sequências em live-action e uma longa sequência animada, inteiramente a cargo de Chomón. A parte em live-action é o centro propulsor da narrativa, e, à animação, é dado mostrar o sonho de um garoto cujo pai encontra-se a serviço nas trincheiras da Primeira Guerra Mundial.

Com a família, o pequeno Momi aguarda notícias do pai, um oficial italiano em combate na frente alpina. Notícias chegam através de uma carta, cujas informações dão-se a conhecer através de um flashback. As novidades do front mexem com a imaginação do garoto, que, impressionado, vai brincar com seus bonecos. Momi pega no sono, e eis a deixa para iniciar-se uma longa sequência onírica, protagonizada pelos irritadiços Trik e Trak. No sonho de Momi, seus bonecos revelam diferenças inconciliáveis, as quais procuram resolver à base de sopapos. Esgotada fase dos tabefes, Trik e Trak convocam seus exércitos para digladiarem-se manu militari. É então que o filme alude a eventos da Primeira Guerra, quando a Itália enfrentava-se com o Império Austro-Húngaro, poderoso aliado das Potências Centrais.

Animada pelo stop-motion, a sequência onírica de La guerra e il sogno di Momi funciona como um pequeno documentário sobre a Primeira Guerra Mundial. Primeiro conflito do século a utilizar as tecnologias modernas, esta guerra estreou armas novas e letais, como um canhão de 70 toneladas, capaz de lançar bombas de 800 quilos a uma distância de 12 quilômetros, usado pelos alemães. No sonho de Momi, essa arma ganha a forma do canhão Kolossal, causador de dezenas de baixas nas tropas de Trik. Além das bombas, o canhão "vomita vapores asfixiantes", para alcançar uma "vitória relâmpago", e, também aqui, a referência é aos alemães, então usuários de armas químicas contra os países Aliados. Os homens de Trik não deixam por menos e bolam um aparato para sugar os "gases mefíticos": trata-se de um fole, acoplado a uma buzina, que suga o gás através de um movimento reverso no filme. E qual é a brilhante 
estratégia dos Triks para evitar os tiros de canhão dos Traks? Penetrar no arsenal inimigo e escrever um recado em suas bombas: "Retorno ao remetente" (figura 6).

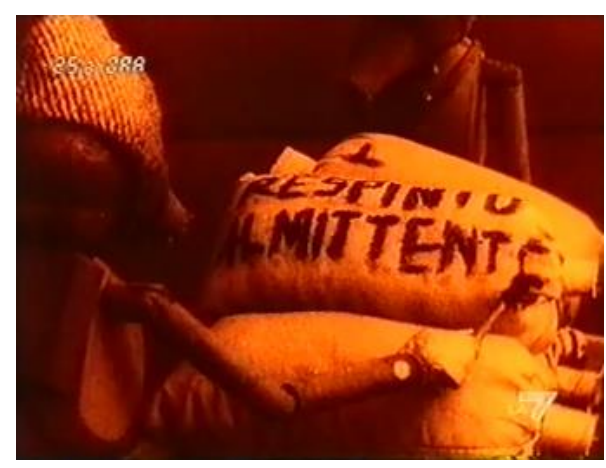

Figura 6 - La guerra e il sogno di Momi

A guerra imaginária de Momi continua com uma "batalha nas nuvens": os Traks aparecem num dirigível, lançando bombas ao país dos Triks, referência aos bombardeios alemães contra a França e a Inglaterra, a partir de zepelins. A desova das bombas é seguida de planos mostrando a destruição em terra. Casas voam pelos ares, prédios ardem em chamas, corpos explodem. Felizmente, tudo não passa de um sonho, e volta-se ao mundo real, onde o duelo dos bonecos continua sobre o corpo do pequeno Momi. Como não está terminada no mundo físico, a guerra não pode se concluir com a vitória de qualquer das partes no filme, que termina com o despertar de Momi, espetado pela baioneta de Trak.

Embora cômica, a visão da guerra desvelada pelo curta-metragem animado de Chomón instila pessimismo. O sonho do menino mostra o que o live-action não se atreveria a mostrar: cidades destruídas, confusão generalizada, morte em escala industrial. Era também esse o saldo colhido pela Europa, após criar para si um conflito de barbárie sem precedentes e sem nenhuma previsão de término. $A$ guerra que começara tendo na tecnologia moderna um de seus pilares prestava uma folha de desserviços à humanidade. Não era bem o panorama esperado para um século inaugurado sob a égide do racional. O que viria a seguir? Eis a pergunta deixada por um filme algo desesperançado, concluindo-se com uma peroração aos céus, no "sagrado voto daqueles que esperam". 


\section{VII - Conclusão}

No alvorecer do século XX, o cinema provocava interrogações. A que se prestaria um tal dispositivo, para além da função óbvia de registrar o "movimento real da vida"? Chomón dedicou a carreira a formular respostas a essa pergunta: seus filmes desafiaram limites técnicos, abriram novos caminhos, atenderam à necessidade experimental daquele primeiro cinema. A animação se destacou na filmografia chomoniana, funcionando, para o espanhol, como um fecundo território de investigação. Dotada de misteriosa qualidade visual, era ainda uma dimensão desconhecida das imagens móveis, criando, nas telas, ilusões muito próximas às de um sonho. O diretor, cuja função passava basicamente por engendrar sonhos, compreendeu estar diante de um novo filão cinemático: enamorou-se da técnica, usou-a em seus principais filmes, deu sua contribuição para desvendar aquela fascinante "arte dentro da arte". ${ }^{11}$

Longe de ocupar lugar periférico na poética de Chomón, a animação incorporouse ao seu processo criativo. Providencial para um diretor que buscava diferenciar o seu trabalho do de Méliès, orientou a sua filmografia a uma direção mais efetivamente autoral na Pathé-Frères. Estava ali um truque ignorado pelo mágico francês, desdobrável em variantes como o stop-motion de bonecos, de massa plástica, de silhuetas, de fotografias e do que mais viesse à cabeça do realizador. O que poderia haver de mais de mais desafiador para um aficionado dos truques? Chomón fartou-se, pois, em banhar-se nesse manancial, ao que a animação respondeu gratificada, emprestando singularidade aos seus filmes, que se distanciaram a léguas dos filmes de Méliès.

A animação mostrou-se eficaz, por fim, para inserir-se no sistema industrial para o qual o cinema migrou nos anos 1910. Continuou a permear a obra de Chomón na Itália, ensejando a construção dos mais diferentes imaginários em seus filmes transalpinos, em sua maior parte narrativos. Se Segundo de Chomón foi um dos grandes artífices do nascente cinema narrativo de ficção, perfilando-se entre os primeiros mestres dos efeitos especiais, ${ }^{12}$ contribuiu também para fazer aflorar este "outro" cinema, mais solitário e artesanal, território preferencial de artistas dedicados à missão de "encantar a matéria vulgar": o cinema de animação

\footnotetext{
${ }^{11}$ A expressão "arte dentro da arte" é do teórico Paul Wells, que a utiliza como espinha dorsal de seu livro, Animation: genre and authorship (2002).

12 Ver o meu, já citado, Do truque ao efeito especial: o cinema de Segundo de Chomón (Barbosa, 2014).
} 
apenas rastejava quando o espanhol deu-lhe este primeiro influxo de originalidade, abraçando-o como campo dileto de explorações. ${ }^{13}$ Colaborou para tirar a técnica do limbo, libertando bonecos, recortes, desenhos e até corpos humanos para movimentos livres e surreais no seu maravilhoso ecrã encantado.

13 Expressão do poeta francês Guillaume Apollinaire. 


\section{Referências}

BARBOSA, Paulo Roberto de Carvalho. Do truque ao efeito especial: o cinema de Segundo de Chomón. São Paulo: Terceira Margem, 2014.

, Paulo Roberto de Carvalho. O primeiro cinema em cores: tecnologia e estética do filme colorido até 1935. Saarbrücken: Novas Edições Acadêmicas, 2014.

CRAFTON, Donald. Before Mickey: The Animated Film, 1898-1928, Chicago: University of California Press, 1982.

CUENCA, Carlos Fernández. Segundo de Chomón, maestro de la fantasía y de la técnica (1871-1929), Madrid: Editora Nacional, 1972.

GAUDREAULT, André. From Plato to Lumière, narration and monstration in literature and cinema, Toronto: University of Toronto Press, 2009.

GUNNING, Tom. "The cinema of attractions: early film, its spectator and the avant-garde", in ELSAESSER, Thomas (ed.), Early cinema: space-framenarrative, pp. 56-62. Berkeley: British Film Institute, 1990.

MINGUET, J. M.. Segundo de Chomón: el cine de la fascinación. Barcelona: Filmoteca de la Generalitat de Catalunya, 2010.

THARRATS, Juan Gabriel, Inolvidable Chomón - Murcia: Editora Regional de Murcia/Filmoteca Regional de Murcia, 1990.

Universitarias, 1988.

. Los 500 films de Segundo de Chomón. Saragoça: Prensas

VIDAL, Agustín Sánchez. El cine de Chomón. Saragoça: Caja de Ahorros de la Inmaculada Aragon, 1992.

WELLS, Paul. Animation: genre and authorship. Londres: Wallflower Press, 2002.

\section{Consulta à internet}

MERCER, Leigh - "Fear at the hands of technology: The proto-Surrealism of the films of Segundo de Chomón", in Studies in Hispanic Cinemas, no 2, vol. 4, University of Washington: 2007. Acesso em 28/08/2011. Disponível em:

http://www.atypon-link.com/INT/doi/pdf/10.1386/shci.4.2.79_1?cookieSet=1. 